\title{
Relationship between the tropical seagrass bed characteristics and the structure of the associated fish community
}

\author{
Rohani Ambo-Rappe ${ }^{1 *}$, Muhammad Natsir Nessa ${ }^{1}$, Husain Latuconsina ${ }^{2}$, Dmitry L. Lajus ${ }^{3}$ \\ ${ }^{1}$ Department of Marine Science, Faculty of Marine Science and Fisheries, Hasanuddin University, Makassar, Indonesia; \\ *Corresponding Author: rohani.amborappe@gmail.com \\ ${ }^{2}$ Department of Aquatic Resources Management, Faculty of Fishery and Marine Science, Darussalam University, Ambon, Indonesia \\ ${ }^{3}$ Department of Ichthyology and Hydrobiology, Faculty of Biology and Soil Sciences, St. Petersburg State University, St. Petersburg, \\ Russia
}

Received 24 February 2013; revised 6 May 2013; accepted 8 July 2013

Copyright (C) 2013 Rohani Ambo-Rappe et al. This is an open access article distributed under the Creative Commons Attribution License, which permits unrestricted use, distribution, and reproduction in any medium, provided the original work is properly cited.

\begin{abstract}
Structural complexity of seagrass bed including species composition and shoot density is argued to be an important factor determining fish assemblages. However statistical verification of such a relationship is possible only in areas with high species richness of seagrass and fish assemblages which is observed in tropical waters. Material for this study was collected in three seagrass beds with different structure in Inner Ambon Bay, Eastern Indonesia. This study provided evidence that higher structural complexity of seagrass bed was related to the higher richness, abundance, and biomass of fish. However, lower structural complexity of seagrass patch should not be underestimated because it provided different habitat for various stages of life in fish. Smaller fish preferred to occupy dense seagrass of dominant pioneer small-sized species (Halodule uninervis) and moved to the lesser dense bed of climax large-sized seagrass (Thalassia hemprichii and Enhalus acoroides) with increasing their size. This finding is important for seagrass-fisheries management.
\end{abstract}

Keywords: Fish; Tropical Seagrass; Structural Complexity; Enclosed Bay; Fisheries Management

\section{INTRODUCTION}

Seagrasses are submerged aquatic plants inhabiting marine coastal waters; they occur in the intertidal zone and in deeper areas. They grow in beds and often form extensive underwater meadows. Seagrasses comprise complex communities, which include the plants and their associated flora and fauna [1]. The presence of segrasses enhances the marine environment by increasing the amount of physical structure and thereby increasing the available habitat and, consequently, increasing the abundance and diversity of marine organisms [2]. Leaves and stems of seagrasses support numerous and abundant epiphytes which are fed upon by small epifaunal organisms [3], which, in turn, provide food to the fishes foraging in the seagrass beds $[1,4,5]$. Fish may use seagrass for the following purposes: temporary nursery, permanent habitat for completion of the full life cycle, feeding area for various life stages, and/or refuge from predation [6,7].

Seagrass beds are widely distributed in the tropical Indo-Pacific region. They often occur adjacent to coral reefs and mangrove forests. Overall, there are 60 described species of seagrasses worldwide, within 12 genera, 4 families and 2 orders [8,9]. Seagrasses range from small plants with thin leaves to large plants with thick leaves. The order from small to large genera is the following: Halophila $<$ Halodule $<$ Ruppia $<$ Zostera/ Heterozostera $<$ Phyllospadix $<$ Cymodocea $<$ Syringodium $<$ Amphibolis $<$ Thalassodendron $<$ Thalassia $<$ Enhalus $<$ Posidonia [10]. Indonesian waters house about 12 species of seagrass from 7 genera which inhabit about $30,000 \mathrm{~km}^{2}$ of the Indonesian coastal zone. They occur in the form of monospecific (constructed by only one species of seagrass) or multispecific beds (constructed by two or more species of seagrass). Indonesian seagrass meadows are generally multispecific with up to 8 seagrass species constructed one bed [11], however, monotypic beds of seagrasses made up of Enhalus acoroides or Thalassia hemprichii do occur [12]. 
The importance of seagrass bed as a habitat and food source for marine animals is expected to vary with the species composition of seagrass. Some researchers found the differences of fish assemblages in seagrass bed represented by different species of seagrass [13-16]. Moreover, Ambo-Rappe (unpublished work) found the abundance and species diversity of fishes were higher in multispesific seagrass bed with high shoot density, compared to the monospesific seagrass bed and multispesific bed with low shoot density. The richness of seagrass species may influence faunal assemblages because more diverse seagrass provide greater structural complexity and therefore more niches for the associated plants and animals. The physical nature of the seagrass canopy is thought to play a major role, potentially influencing available shelter, food, and protection from predators [17]. This fact is raising a concern on the role of seagrass diversity on their ecological function in marine ecosystems, in particular, because there is a tendency of declining and/or extinction of certain species of seagrass due to climate change and other factors [18].

Different size of seagrass beds also affect the colonization of the beds by marine organisms [19-21]. The general prediction from research on terrestrial systems is decrease in abundance and diversity in fragmented habitats [22]. This is due to the increased negative impacts, such as radiation, wind, and water movement that act across smaller patches rather than in larger ones. Moreover, large patches provide greater interior areas, decreasing edge impact which is mostly associated with increased in predation [23]. Conversely, studies in seagrass systems suggest that many small seagrass patches with higher perimeter-area ratio may increase the overall probability of encounter by larvae or other immigrants, thereby increasing overall colonization of the patch compared to larger patches [24,25]. Moreover, the large amount of edges associated with patchy seagrass beds may facilitate penetration of water and food to the interior part of seagrass patches [26]. Whereas, significantly greater total number of infaunal macroinvertebrate taxa was found in samples from large rather than small patches of seagrass $[20,27]$. Therefore, there is no consistency of the results on the effect of patch size on the abundance of resident fauna. The effect of habitat size on associated fauna may be different for different species and is highly site- and taxon-specific [28].

Few studies have been investigated how abundance and structure of assemblages of seagrass fauna vary among different species of seagrass [29]. This information is particularly important for tropical area, where many species of seagrass occur together in one meadow. The structural complexicity of the meadow involving different seagrass species is also need to be considered.

Effect of seagrass bed characteristics composing of different species of seagrass on fish communities is not easy to analyze because species richness is generally not very large. Low number of species causes difficulties of obtaining statistically significant effects. Because of that, study involving many species, i.e. carried in tropical ecosystems, are of special interest.

The objective of this study was to analyze relationship between characteristics of seagrass bed such as species composition, shoot density, and patch area, and the structure of associated fish community in the tropical seagrass ecosystem.

\section{MATERIALS AND METHODS}

\subsection{Study Site}

This study was conducted in March - May 2011 in the inner Ambon Bay, Maluku Province, eastern Indonesia (Figure 1). Ambon Bay consists of two parts (inner and outer) separated by a narrow sand bar with $12-\mathrm{m}$ depth, and characterized by different hydrological conditions. The outer bay is deeper (up to $800 \mathrm{~m}$ down the slopes) with high coral cover and connect directly to the open Banda sea, while the inner bay is shallower (a maximum depth of $40 \mathrm{~m}$ ) and mainly fringed by seagrass and mangrove (personal communication).

The inner Ambon Bay has an area of $11.72 \mathrm{~km}^{2}$ and $18.30 \mathrm{~km}$ of coastal line. It is a semi enclosed estuarine bay and previously well known for its support for livebait fisheries for supplying skipjack fisheries [30].

This bay is characterized by tropical monsoonal climate, which has dry season (December-February), transitional I (March-May), rainy season (June-August), and transitional II (September-November). Water temperature and salinity fluctuate seasonally with water temperature in the range of $24.5^{\circ} \mathrm{C}-31.0^{\circ} \mathrm{C}$ and the salinity of $27.0-33.3$. Relatively small amount of water discharges into the bay from rivers correspond to the small contribution of the rivers in the fluctuation of temperature and salinity in this bay (personal communication).

This inner bay hosts a multispesific seagrass composed

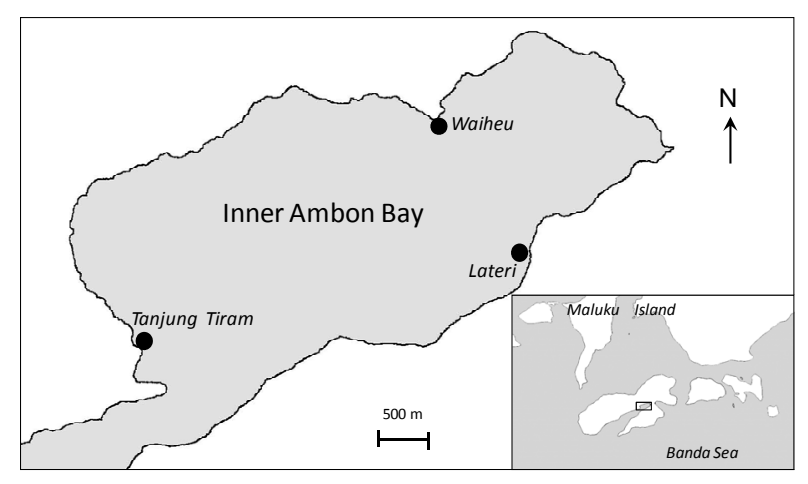

Figure 1. Study site in the inner Ambon Bay, eastern Indonesia. 
of four species, namely Enhalus acoroides, Thalassia hemprichii, Halodule uninervis, and Halophila ovalis. The former three species of seagrass produce long straplike leaves, whereas the latter has oval-shaped leaves. Both leaf length and width differ between species. E. acoroides leaves are the biggest with $300-2000 \mathrm{~mm}$ long and 12 - $20 \mathrm{~mm}$ wide, followed by T. hemprichii (length; 100 - $400 \mathrm{~mm}$, width; 4 - $11 \mathrm{~mm}$ ), H. uninervis (length; 60 - $150 \mathrm{~mm}$, width; 0.3 - $4 \mathrm{~mm}$ ), and $H$. ovalis (length; 10 $40 \mathrm{~mm}$, width; 5 - $20 \mathrm{~mm}$ ) [9,31].

The composition of seagrass vary from one place to another in the bay. There were three stations selected for this study based on number of seagrass species occurred in a meadow, namely: 1) Tanjung Tiram (03 39 'S; $\left.128^{\circ} 12^{\prime} \mathrm{E}\right)$ located near the entrance of the bay and has approximately $200 \mathrm{~m} \times 130 \mathrm{~m}$ seagrass area comprising of four species of seagrass, E. acoroides, T. hemprichii, $H$. uninervis, and $H$. ovalis; 2) Lateri ( $03^{\circ} 38^{\prime} \mathrm{S}$; $\left.128^{\circ} 13^{\prime} \mathrm{E}\right)$ located further inside the bay and has approximately 200 $\mathrm{m} \times 70 \mathrm{~m}$ seagrass bed consists of two species of seagrass E. acoroides and T. hemprichii; 3) Waiheru $\left(03^{\circ} 37 \mathrm{~S}\right.$; $128^{\circ} 12^{\prime} \mathrm{E}$ ) located opposite to the second station and consists of an approximately $200 \mathrm{~m} \times 60 \mathrm{~m}$ monotypic seagrass patch, E. acoroides. The distance between the stations is approximately $2-3 \mathrm{~km}$.

Oceanographic parameters such as depth, temperature, salinity, $\mathrm{pH}$, dissolved oxygen measured during the study showed that intra-site variation notably exceeds variation among sites and range from 1.0 to $1.5 \mathrm{~m}, 28.90^{\circ} \mathrm{C}$ to $31.40^{\circ} \mathrm{C}, 30.10$ to $33.30 \mathrm{ppt}, 7.91$ to 8.28 , and 5.49 to 6.71 $\mathrm{mg} / \mathrm{l}$, respectively.

\subsection{Estimation of Seagrass Shoot Density}

Seagrass density measurement was performed in each station on March 2011 by using a systematic sampling method according to [32]. Three $100 \mathrm{~m}$ line transects were placed perpendicular to shoreline in each station. The distance between the line transects within each station was $25 \mathrm{~m}$. Ten quadrates $(1 \mathrm{~m} \times 1 \mathrm{~m}$ each $)$ were regularly deployed in each line transect with the distance of $10 \mathrm{~m}$ from each other. Seagrass were collected from a sub sample of $20 \mathrm{~cm} \times 20 \mathrm{~cm}$ within each $1 \mathrm{~m} \times 1 \mathrm{~m}$ quadrate and washed from sediment remains before being separated to species based on [31]. Then the shoot density of each seagrass species was counted. Sample of sediment was also taken from each sub quadrate for sediment grain size analysis. Sediment samples were dry-sieved using standard laboratory test sieves of mesh sizes $2.0 \mathrm{~mm}, 1$ $\mathrm{mm}, 0.5 \mathrm{~mm}, 0,25 \mathrm{~mm}, 0.125 \mathrm{~mm}$, and $0.063 \mathrm{~mm}$.

\subsection{Fish Sampling}

Fish sampling was conducted once a month at mid-low tide with a beach seine (1.5 m wide, $15 \mathrm{~m}$ long, and 500 $\mu \mathrm{m}$ mesh) on each seagrass meadow. The beach seine was dropped in the water and manually dragged $100 \mathrm{~m}$ over the seagrass bed. Two parallel beach seining were performed at each station and each sampling occassion in order to cover the whole seagrass meadow and reduce sampling bias of the fish. All fish collected were counted, identified to species based on standard methods [33-35], and measured for weight (to the nearest $0.01 \mathrm{~g}$ ) and total length (to the nearest $0.1 \mathrm{~cm}$ ).

There were only five species found in a wide range of individual length sizes, namely Siganus canaliculatus, Aeoliscus strigatus, Syngnathoides biaculeatus, Acreichthys tomentosus, and Paracentropogon longispinis. Large individuals of these species (S. canaliculatus; 16.0 $28.3 \mathrm{~cm}$, A. strigatus; 12.0 - $16.8 \mathrm{~cm}$, S. biaculeatus; 19.0 - $28.3 \mathrm{~cm}$, A. tomentosus; $8.0-10.5 \mathrm{~cm}$, and $P$. longispinis; $8.0-9.7 \mathrm{~cm}$ ) were also analyzed for their gonad maturity. Then, all individual fish were grouped into juveniles and adults according to length at first maturation available in literature $[33,35]$ and from own analysis of gonad.

\subsection{Data Analysis}

Univariate data analyses (ANOVA) were used to analyse differences in species richness, abundance of individual fish, and fish biomass ( $\mathrm{g}$ wet-W) among the three stations with different characteristics of seagrass bed. A Bonferroni post hoc test was used for comparison of treatment means when an F-test indicated significant ( $p$-value $<0.05)$. Before performing ANOVA, all data were tested for normality and homogeneity of variances. Spatial similarity in fish species composition among stations was additionally analyzed using presence or absence of species at each station. Juveniles and adults of five dominant species were analyzed separately to reveal age-specific patterns of species distribution among stations.

\section{RESULTS}

Shoot density of seagrass decreased in the row Tanjung Tiram-Lateri-Waiheru (Table 1). Seagrass bed area in Tanjung Tiram were also wider compared to other two stations. Sediment characteristics varied among locations and Tanjung Tiram had higher content of coarse, medium, and fine sand. Waiheru and Lateri, on the other hand, had higher content of very fine sediment and clay (Figure 2).

A total of 9189 individual fish representing 95 species from 38 families were collected at the three stations. Due to the lack of differences in the fish species richness, abundance and biomass between months (one-way ANOVA, $p>0.05$ ), data obtained in different months were pooled, and further analysis was only done on the spatial differences of these parameters between the three distinct seagrass beds.

Five species, which had the widest range of individual 
Table 1. Shoot density of seagrass species in each station.

\begin{tabular}{ccccc}
\hline \multirow{2}{*}{ Stations } & \multicolumn{4}{c}{ Shoot density (number of shoot $\mathbf{m}^{2}$; mean $\pm \mathbf{S E}, \boldsymbol{n}=\mathbf{3 0}$ ) } \\
\cline { 2 - 5 } & Enhalus acoroides & Thalassia hemprichii & Halodule uninervis & Halophila ovalis \\
\hline Tanjung Tiram & $20.67 \pm 1.77$ & $16.89 \pm 2.33$ & $56.89 \pm 13.70$ & $4.89 \pm 0.89$ \\
Lateri & $13.40 \pm 1.31$ & $11.00 \pm 1.62$ & & \\
Waiheru & $9.00 \pm 0.28$ & & & \\
\hline
\end{tabular}

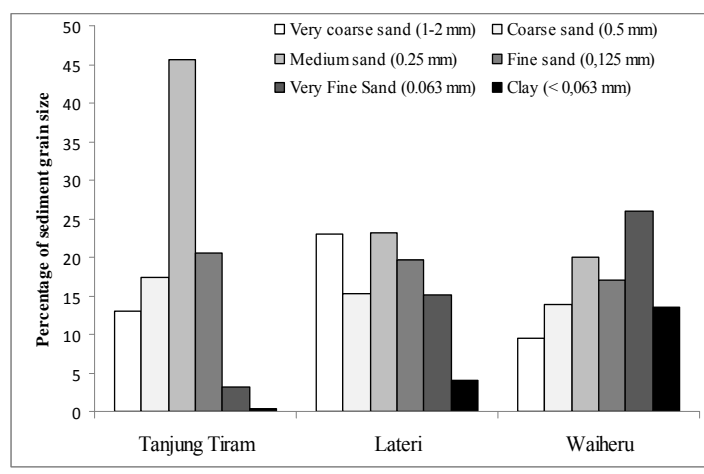

Figure 2. Sediment composition at three stations.

length sizes (Siganus canaliculatus, Aeoliscus strigatus, Syngnathoides biaculeatus, Acreichthys tomentosus, and Paracentropogon longispinis) had also higher number of individuals compared to the others and found in all three stations, with exception of $P$. longispinis which was not found in Waiheru station (Table 2).

These five species accounted for $70 \%$ of the total abundance: S. canaliculatus (50.1\%), A. strigatus (9.9\%), S. biaculeatus $(5.0 \%), A$. tomentosus $(3.4 \%)$, and $P$. longispinis (2.3\%). The result of gonad analyses showed that individuals of the five dominant fishes had mature gonad (and thus considered adult) at minimum sizes of $17.2,12.7,20.0,8.7$, and $8.5 \mathrm{~cm}$ length, respectively.

Based on information from gonad analyses and available literatures on the first maturation size of fish, a high proportion (89\%) of all fish collected in this study was categorized as juvenile. Each of the dominant species classified into juvenile and adult (Table 3) showed that Lateri and Waiheru had higher percentage of adult fish compared to Tanjung Tiram. Almost $66 \%$ of A. strigatus in adult stage were found at Lateri, while $S$. canaliculatus and S. biaculeatus were found in $86 \%$ and $70 \%$, respectively, as adults in Waiheru.

The number of species and abundance were significantly different among stations (ANOVA: number of species; $\mathrm{F}=4.569, \mathrm{p}<0.05$, abundance; $\mathrm{F}=3.714, \mathrm{p}<$ $0.05)$. Tanjung Tiram had significantly higher species richness and abundance of individual fish than Waiheru. However, no significant differences were found after the Bonferroni test between Tanjung Tiram and Lateri, and also between Lateri and Waiheru. Fish biomass was significantly lower in Waiheru compared to the other two stations $(F=9.420, p<0.01)$ (Figure 3$)$. There were

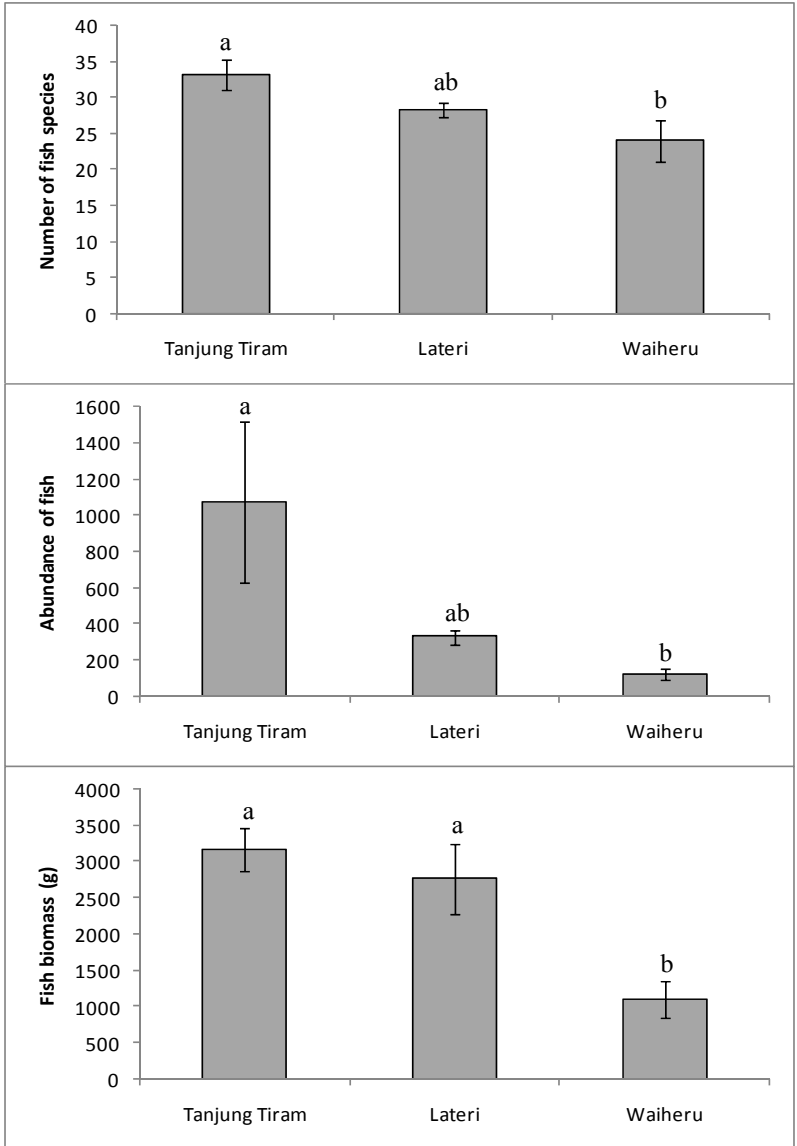

Figure 3. Mean number of fish species, fish abundance and biomass (mean $\pm \mathrm{SE}, n=6$ ).

$31.6 \%$ of fish species common in the three stations, whereas similarity in species composition between stations as follow: Tanjung Tiram-Lateri (43.2\%), Tanjung Tiram-Waiheru (40.0\%), and Lateri-Waiheru (42.1\%) (see also Table 2)

\section{DISCUSSION}

Seagrass habitats are associated with shallow waters and often reported to have high abundance of juvenile fishes [36-39]. This habitat therefore is referred to as nursery habitat which may increase the probability of juvenile's survival through the provision of food and shelter. Increased food is thought to increase growth rates, which in turn facilitates lower mortality. The structural 
Table 2. Fish species, number of individual, and length of fish collected in each station.

\begin{tabular}{|c|c|c|c|c|c|c|}
\hline \multirow{2}{*}{ Name of family and species } & \multicolumn{3}{|c|}{ Stations } & \multirow{2}{*}{$\begin{array}{l}\text { Total number } \\
\text { of individuals }\end{array}$} & \multirow{2}{*}{ Length (cm) } & \multirow{2}{*}{$\begin{array}{c}\text { Adult size } \\
\text { theory } \\
(\mathrm{cm})\end{array}$} \\
\hline & $\begin{array}{c}\text { Tanjung } \\
\text { Tiram }\end{array}$ & Waiheru & Lateri & & & \\
\hline \multicolumn{7}{|l|}{ I. APOGONIDAE } \\
\hline Apogon sp. & + & - & - & 1 & 3.5 & $5)^{*}$ \\
\hline Apogon fragilis (Smith, 1961) & - & + & - & 2 & $1.9 \& 2.5$ & $5)^{*}$ \\
\hline Apogon hoevenii (Bleeker, 1854) & + & + & + & 16 & $3.5-5.5$ & $5)^{*}$ \\
\hline Apogon melas (Bleeker, 1848) & + & - & - & 1 & 7.6 & $10)^{* *}$ \\
\hline Cheilodipterus quinquelineatus (Cuvier, 1828) & + & + & - & 17 & $1.60-5.7$ & $12)^{*}$ \\
\hline Fowleria variegata (Valenciennes, 1832) & + & - & - & 2 & $3.5 \& 4.0$ & $8)^{*}$ \\
\hline \multicolumn{7}{|l|}{ II. BALISTIDAE } \\
\hline Balistoides viridescens (Bloch and Schneider, 1801) & - & - & + & 2 & $4.0 \& 5.4$ & $60)^{*}$ \\
\hline \multicolumn{7}{|l|}{ III. BLENNIIDAE } \\
\hline Petroscirtes mitratus (Rüppell, 1830) & + & + & + & 5 & $4.3-7.5$ & $8)^{* *}$ \\
\hline Petroscirtes variabilis (Cantor, 1850) & + & + & + & 29 & $2.7-9.0$ & $12)^{* *}$ \\
\hline \multicolumn{7}{|l|}{ IV. BOTHIDAE } \\
\hline Bothus pantherinus (Rüppell, 1830) & - & + & + & 7 & $6.2-17.5$ & $24)^{*}$ \\
\hline Engyprosopon grandisquama (Temminck \& Schlegel, 1846) & - & + & - & 1 & 9.4 & $13)^{*}$ \\
\hline Pardachirus pavoninus (Lacepède, 1802) & + & - & - & 1 & 5.7 & $25)^{*}$ \\
\hline \multicolumn{7}{|l|}{ V. CALLIONYMIDAE } \\
\hline Callionymus sp & + & + & + & 20 & $2.5-5.8$ & $12)^{*}$ \\
\hline Dactylopus dactylopus (Valenciennes, 1837) & - & + & + & 6 & $5.0-18.0$ & $30)^{*}$ \\
\hline \multicolumn{7}{|l|}{ VI. CARANGIDAE } \\
\hline Caranx sexfasciatus (Quoy \& Gaimard, 1825) & - & + & + & 13 & $4.5-12.9$ & $42)^{* *}$ \\
\hline Trachinotus blochii (Lacepède, 1801) & - & + & - & 1 & 15.0 & $58)^{*}$ \\
\hline Carangoides uii (Waklya, 1924) & - & + & + & 5 & $5.6-11.5$ & $25)^{*}$ \\
\hline Gnathanodon speciosus (Forsskal, 1775) & - & + & + & 3 & $4.3-7.0$ & $100)^{* *}$ \\
\hline \multicolumn{7}{|l|}{ VII. CAESIONIDAE } \\
\hline Caesio caerulaurea (Lacepède, 1801) & - & + & - & 1 & 4.5 & $35)^{*}$ \\
\hline \multicolumn{7}{|l|}{ VIII. CENTRISCIDAE } \\
\hline Aeoliscus strigatus (Günther, 1860) & + & + & + & 911 & $3.0-16.8$ & $14)^{*}$ \\
\hline \multicolumn{7}{|l|}{ IX. CHAETODONTIDAE } \\
\hline Parachaetodon ocellatus (Cuvier, 1831) & + & + & - & 5 & $5.4-8.3$ & $18)^{*}$ \\
\hline Heniochus acuminatus (Linnaeus, 1758) & + & + & - & 9 & $3.0-8.3$ & $20)^{*}$ \\
\hline \multicolumn{7}{|l|}{ X. CYNOGLOSSIDAE } \\
\hline Paraplagusia bilineata (Bloch, 1787) & - & + & - & 1 & 7.0 & $25)^{*}$ \\
\hline \multicolumn{7}{|l|}{ XI. ENGRAULIDAE } \\
\hline Stolephorus indicus (van Hasselt, 1823) & - & + & - & 27 & $3.3-4.7$ & $12)^{* *}$ \\
\hline
\end{tabular}




\section{Continued}

XII. DACTYLOPTERIDAE

Dactyloptena orientalis (Cuvier, 1829)

XIII. FISTULARIDAE

Fistularia petimba (Lacepède, 1803)

XIV. GERREIDAE

Gerres oyena (Forsskal, 1775)

XV. GOBIIDAE

Acentrogobius sp

Amblygobius phalaena (Valenciennes, 1837)

Exyrias belissimus (Smith, 1959)

Yongeichthys nebulosus (Forskal, 1775)

Istigobius decoratus (Herre, 1927)

XVI. HAEMULIDAE

Diagramma labiosum (Macleay, 1883)

XVII. LABRIDAE

Choerodon anchorago (Bloch, 1791)

Halichoeres argus (Bloch and Schneider, 1801)

Halichoeres chloropterus (Bloch, 1791)

Halichoeres melanurus (Bleeker, 1851)

Halichoeres scapularis (Bennett, 1831)

Halichoeres schwartzii (Bleeker, 1849)

Cheilinus chlorourus (Bloch, 1791)

Stethojulis interrupta (Bleeker, 1851)

XVIII. LETHRINIDAE

Lethrinus harak (Forsskal, 1775)

Lethrinus lentjan (Lacepède, 1802)

Lethrinus ornatus (Valenciennes, 1830)

Lethrinus variegatus (Valenciennes, 1830)

Lethrinus sp

XIX. LEIOGHNATHIDAE

Gazza minuta (Bloch, 1797)

\section{LUTJANIDAE}

Lutjanus biguttatus (Valenciennes, 1830)

Lutjanus fulviflamma (Forsskal, 1775)

Lutjanus fulvus (Forster, 1801)

Lutjanus lutjanus (Bloch, 1790)

XXI. MONACANTHIDAE 


\section{Continued}

Acreichthys tomentosus (Linnaeus, 1758)

312

$2.7-10.5$

$12)^{*}$

\section{MULLIDAE}

Mulloidichthys vanicolensis (Valenciennes, 1831)

Parupeneus barberinus (Lacepède, 1801)

Parupeneus indicus (Shaw, 1803)

Upeneus tragula (Richardson, 1846)

\section{MURAEINIDAE}

Gymnothorax richardsoni (Bleeker, 1852)

XXIV. NEMIPTERIDAE

Pentapodus trivittatus (Bloch, 1791)

Scolopsis ciliata (Lacepède, 1802)

XXV. OSTRACIIDAE

Lactoria cornuta (Linnaeus, 1758)

XXVI. PLATUCEPHALIDAE

Inogocia sp

Platycephalus indicus (Linnaeus, 1758)

\section{PLOTOSIDAE}

Plotosus anguillaris (Bloch, 1794)

XXVIII. POMACENTRIDAE

Pomacentrus tripunctatus (Cuvier, 1830)

\section{SCARIDAE}

Scarus sp

Leptoscarus vaigiensis (Quoy and Gaimard, 1824)

\section{SERRANIDAE}

Centrogenys vaigiensis (Quoy \& Gaimard, 1824)

Cephalopholis boenack (Bloch, 1790)

Epinephelus coioides (Hamilton, 1822)

Epinephelus maculatus (Bloch, 1790)

\section{SOLEIDAE}

Phyllichthys punctatus (McCulloch, 1916)

\section{SYNGNATHIDAE}

Corythoichthys intestinalis (Ramsay, 1881)

Doryrhamphus dactyliophorus (Bleeker, 1853)

Hippocampus kuda (Bleeker, 1852)

Syngnathoides biaculeatus (Bloch, 1785)

XXXIII. SCORPAENIDAE

Inimicus didactylus (Pallas, 1769)

$\begin{array}{ccc}2 & 8.0 \& 8.1 & 24)^{*} \\ 322 & 4.7-16.5 & 30)^{*} \\ 1 & 9.0 & 40)^{*} \\ 29 & 5.0-13.3 & 30)^{* *} \\ 4 & 18.7-21 & 30)^{*}\end{array}$

\section{5}

170

18

$1.8-13.7$

$46)^{*}$

$+\quad+\quad+\quad+18$

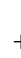




\section{Continued}

Paracentropogon longispinis (Cuvier, 1829)

Pterois volitans (Linnaeus, 1758)

Scorpaenopsis sp

Scorpaenopsis venosa (Cuvier, 1829)

Synanceja horrida (Linnaeus, 1766)

XXXIV. SIGANIDAE

Siganus argenteus (Quoy and Gaimard, 1825)

Siganus canaliculatus (Park, 1797)

Siganus doliatus (Cuvier, 1830)

Siganus lineatus (Linnaeus, 1835)

Siganus punctatus (Schneider, 1801)

XXXV. SPHYRAENIDAE

Sphyraena pinguis (Günther, 1874)

XXXVI. SYNODONTIDAE

Saurida gracilis (Quoy \& Gaimard, 1824)

Saurida tumbil (Bloch, 1795)

XXXVII. TERAPONTIDAE

Pelates quadrilineatus (Bloch, 1790)

XXXVIII. TETRAODONTIDAE

Arothron immaculatus (Bloch and Schneider, 1801)

Arothron manilensis (Marion de Procé, 1822)

Arothron reticularis (Bloch and Schneider, 1801)

Arothron stellatus (Bloch and Schneider, 1801)

Chelonodon patoca (Hamilton, 1822)

$\begin{array}{ll}+ & - \\ - & - \\ + & - \\ + & + \\ - & +\end{array}$

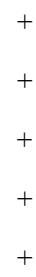

210

$4.0-9.7$

$13)^{* *}$

1

10.7

$38)^{*}$

$4.6-8.8$

$18)^{*}$

15

$1.0-13.5$

$18)^{*}$

2

$7.5 \& 10.0$

47) ${ }^{*}$

$\begin{array}{llll}- & - & - & 1\end{array}$

4.5

$20)^{* *}$

4603

$2.3-28.3$

18)

3

$2.6-7.5$

$20)^{*}$

3.8

$30)^{*}$

1

$2.2-5.8$

24)

$\begin{array}{lll}+ & + & \\ + & & \end{array}$

4

$8.7-13.5$

$35)^{* *}$

$+\quad+\quad+\quad 135$

135

$3.7-17.5$

$28)^{* *}$

15.6

$43)^{*}$

$+$

193

$3.0-10.8$

$20)^{* *}$

$\begin{array}{llllll}+ & + & - & 5 & 2.5-20.7 & 30)^{*} \\ + & + & + & 51 & 1.8-19.5 & 31)^{*} \\ + & + & + & 45 & 2.2-25.0 & 30)^{*} \\ + & + & + & 3 & 16.5-34.4 & 90)^{*} \\ + & + & + & 72 & 1.5-14.2 & 20)^{*}\end{array}$

Note: (+) Found, (-) Not Found, $)^{*}=$ Allen (1999), $)^{* *}=$ Kuiter \& Tonozuka (2001).

Table 3. Percentage of juvenile and adult in five dominant species at each station.

\begin{tabular}{|c|c|c|c|c|c|c|}
\hline \multirow{3}{*}{ Dominant Species } & \multicolumn{6}{|c|}{ Station } \\
\hline & \multicolumn{2}{|c|}{ Tanjung Tiram } & \multicolumn{2}{|c|}{ Lateri } & \multicolumn{2}{|c|}{ Waiheru } \\
\hline & Juvenile & Adult & Juvenile & Adult & Juvenile & Adult \\
\hline Siganus canaliculatus & 99.9 & 0.1 & 98.0 & 2.0 & 14.0 & 86.0 \\
\hline Aeoliscus strigatus & 43.6 & 56.4 & 34.2 & 65.8 & 100.0 & 0.0 \\
\hline Syngnathoides biaculeatus & 69.5 & 30.5 & 55.7 & 44.3 & 30.0 & 70.0 \\
\hline Acreichthys tomentosus & 89.1 & 10.9 & 64.1 & 35.9 & 67.5 & 32.5 \\
\hline Paracentropogon longispinis & 51.4 & 48.6 & 52.2 & 47.8 & 0.0 & 0.0 \\
\hline
\end{tabular}

complexity of seagrass habitats is also considered to provide shelter from predators [40].

In this study, approximately $89 \%$ of fish were found to be juveniles. This fact may suggest that seagrass in inner
Ambon Bay act as a nursery habitat for the fishes around that area. However, care should be taken for this conclusion as in [41] suggested examination of several factors beside juvenile density, such as juvenile survival, 
growth, and movement to adult habitats in order to confirm whether a habitat is a nursery. In most cases, however, higher density of juveniles in coastal water allows to interpret them as nurseries. Moura et al. [42] found juvenile of a reef fish dog snapper (Lutjanus jocu) (size $<$ $7 \mathrm{~cm}$ ) associated with estuarine habitat and moved offshore with increasing size and then considered the estuary as a nursery ground of this fish. Seagrass and mangrove were also considered as nursery habitats for some coral reef fishes after finding higher densities of juveniles in these habitats and observing the pattern of migration of the fish to the coral reefs at increased size $[39,43,44]$.

The composition of seagrass species affected the associated fish communities in this study. Station with more species of seagrass (Tanjung Tiram, 4 species; Lateri, 2 species) had more fish species, and also higher abundance and biomass of fish compared to station with one segrass species (Waiheru). However, numbers of seagrass species occurring in a bed might not be a solely factor contributed to the result. Seagrass bed in Tanjung Tiram and Lateri were also denser, and especially Tanjung Tiram had larger area of seagrass beds as well. Structural complexity (in this case measured as shoot density and number of seagrass species) which was different among stations is considered as a major factor responsible for fish richness. Horinouchi [45] suggested that within-patch structural complexity provides a refuge against predators, attenuation in strong water movements and varied microhabitats, and allows for the coexistence of potentially competing species, thereby supporting high species richness. Horinouchi and Sano [46] found the abundance of juveniles of three gobiid fishes positively increased with the leaf height and shoot density of seagrass Zostera marina. Moreover, Hemminga and Duarte [1] added that high density of seagrass increase the surface area for attachment of microscopic animals and plants (epiphytes) which is the main food for fish.

On the other hand, our study reports an interesting finding when fishes of larger size (up to adult) are more abundant in stations which composed of only one or two species of seagrass with less shoot density (Lateri and Waiheru). Seagrass bed in Lateri was composed of the climax Indo-Pacific seagrass species, Thalassia hemprichii and Enhalus acoroides, and Waiheru was only composed of E. acoroides. We suggested that there would be a movement of fish from Tanjung Tiram (which composed of 4 species of seagrass, but dominated by Halodule uninervis) to Lateri and Waiheru at increased size of fish. Interestingly, this effect can be facilitated by migration patterns on the earlier stages of the life cycle because the Tanjung Tiram is closer to the entrance of that bay and thus may early accept young fish arriving from the open sea. This finding concurred with other studies, for example, Middleton et al. [47] which found smaller fish species and individuals dominated in Zostera beds, whereas larger species and individuals were found in Posidonia. Juveniles of several species were thought to move from Zostera (middle size seagrass) to Posidonia (big size seagrass) with increased size. Kendrick and Hyndes [48] also observed the migration of spotted pipefish Stigmatopora argus from the narrow-leaved Posidonia coriacea to the broad-leaves P. sinuosa. A similar trend was also found in Atlantic croaker (Micropogonias undulatus) and red drum (Sciaenops ocellatus) which smaller sizes occurred in small seagrass (Halodule wrightii) and the bigger ones were in a big seagrass (Thalassia testudinum) [49]. The reason for that movement could be different, Kendrick and Hyndes [48] proposed that the movement of the fish to the broader leaf size with increased size of the fish to enable better camouflaged to prevent predation, and Rooker et al. [49] suggested that fish may select habitat where mortality is lower.

Morphology of seagrass species in term of leaf size (length and width) could be considered as an important factor determining habitat selection by fish at each of their life stage. In this study, beside those parameters, spacing among seagrass shoot could result in the migration of the bigger size of fish. Adult fish due to their bigger size will select bigger space to enable them to move within the seagrass bed and still protecting them from predator by choosing bigger size of seagrass (longer and wider leaf) which have bigger canopy. This result is in line with [15] which stated that fish would select the habitat that match their size showing from their study where bigger size of fish occurred in open space below the canopy of Amphibolis griffithii, while smaller fish able to penetrate and occupied the dense foliage of Posidonia sinuosa. Stoner [50] tested the protective ability of seagrasses and found that for single seagrass species, predation intensity declined with plant surface area, however multi-species seagrass which possessing greatest amount of total surface area provided least amount of protection. The reason for this is that spacing in the dense multi-specific seagrass bed does not match the size of the prey that being attacked by visual predators.

The role of physical factors (e.g. waves) could also be considered in framework of this study as in [29] suggested that wave actions could cover and uncover seagrass patch as seagrass leaves sway back and forth with wave passage, and seagrass may thus provide less protection from predator. In this study, Tanjung Tiram is located next to the mouth of the bay; as a result, wave action in this place is more intense compared to other two stations which located further inside the bay. The result of the stronger wave action could be seen from the sediment grain size 
(Figure 2) that showed Tanjung Tiram has larger percentage of big grain size (sand) compared to other two stations. It could be assumed that protection capacity of seagrass bed in Tanjung Tiram is suitable only for smaller size fish (or juvenile) and became weaker with increasing size of the fish due to the many factors described above. This pattern is also in agreement with a hypothetical model proposed by [51], in which, seagrass bed in Tanjung Tiram due to its close proximity to entrance channel will be firstly encountered by fish larvae leads to increased number of species and individuals in this station. After settling or their size is large enough, individuals redistribute to select the cover of other seagrass bed that favors survival. Distance from the bay entrance with combination with the restricted water circulation within the bay may also limits larva dispersal, and leads to limited juvenile recruitment to seagrass beds further away from the entrance. This finding is similar to [52].

It can be concluded that the specific role of seagrass bed for fish could be determined by its structural complexity (measured by shoot density and seagrass species composition), seagrass surface area, and physical parameters (such as wave and current). All the parameters should be considered together and the effect would be different due to factor interaction for different fish species and their life stage. Smaller patches and less dense of seagrass should not be overlooked because our result demonstrated that these seagrass patches play another role for bigger size and adult fishes. Therefore our study reveals that different life stages of fish may find optimal condition in different seagrass habitats. It means that it is not some particular seagrass habitat is most important for fish community than others, but presence of different seagrass habitats, i.e. their heterogeneity is the most important factor for maintaining fish populations. The role of seagrass meadow as a habitat of fish is well known, however, more study still need to be done to understand many specific questions regarding to this role because it could be site- and species-specific. Identifying what kind of seagrass habitat is used for different fish species and at each life stage of fish is crucial for seagrass-fisheries management.

\section{ACKNOWLEDGEMENTS}

We would like to thank all colleagues who assisted in the field and lab works. Funding for field expenses was provided by COREMAP II and Darussalam University to H.L. Manuscript preparation was partly funded by Indonesian Higher Education (PAR-C) to R.A-R to visit St. Petersburg State University, Russia.

\section{REFERENCES}

[1] Hemminga, M.A. and Duarte, C.M. (2000) Seagrass ecology. Cambridge University Press, Cambridge, 2000.
doi:10.1017/CBO9780511525551

[2] Lee, S.Y., Fong, C.W. and Wu, R.S.S. (2001) The effects of seagrass (Zostera japonica) canopy structure on associated fauna: A study using artificial seagrass units and sampling of natural beds. Journal of Experimental Marine Biology and Ecology, 259, 23-50. doi:10.1016/S0022-0981(01)00221-0

[3] Jernakoff, P. and Nielsen, J. (1998) Plant-animal associations in two species of seagrasses in Western Australia. Aquatic Botany, 60, 359-376. doi:10.1016/S0304-3770(97)00100-9

[4] Kikuchi, T. and Peres, J.M. (1977) Consumer ecology of seagrass beds. In: McRoy, C.P. and Helffrich, C., Eds., Seagrass Ecosystems: A Scientific Perspective, Marcel Dekker, Inc., New York, 147-193.

[5] Edgar, G.J. and Shaw, C. (1995) The production and trophic ecology of shallow-water fish assemblages in southern Australia III: General relationships between sediments, seagrasses, invertebrates and fishes. Journal of Experimental Marine Biology and Ecology, 194, 107-131. doi:10.1016/0022-0981(95)00085-2

[6] Jackson, E.L., Rowden, A.A., Attrill, M.J., Bossey, S.J. and Jones, M.B. (2001) The important of seagrass beds as a habitat for fishery species. Oceanography and Marine Biology, 39, 269-303.

[7] Nakaoka, M. (2005) Plant-animal interactions in seagrass beds: Ongoing and future challenges for understanding population and community dynamics. Population Ecology, 47, 167-177. doi:10.1007/s10144-005-0226-Z

[8] Den Hartog, C. and Kuo, J. (2006) Taxonomy and biogeography of seagrasses. In: Larkum, A.W.D., Orth, R.J. and Duarte, C.M., Eds., Seagrasses: Biology, Ecology and Conservation, Springer, The Netherlands, 1-24.

[9] Den Hartog, C. (1970) The seagrasses of the world. North Holland Publishing Co., Amsterdams.

[10] Butler, A. and Jernakoff, P. (1999) Seagrass in Australia: strategic review and development of an R \& D plan. Csiro, Collingwood.

[11] Kuriandewa, T.E., Kiswara, W., Hutomo, M. and Soemodihardjo, S. (2003) The seagrasses of Indonesia. In: Green, E.P. and Short, F.T., Eds., World Atlas of Seagrasses, University of California Press, Barkeley, 172-182.

[12] Kiswara, W. (1994) A review: Seagrass ecosystem studies in Indonesian waters. In: Wilkinson, C.R., Sudara, S. and Chou, L.M., Eds., Proceeding on the ASEAN-Australia Symposium on Living Coastal Resources, Chulalongkorn University, Bangkok, 259-282.

[13] Toyohara, T., Nakaoka, M. and Aioi, K. (1999) Population dynamics and reproductive traits of phytal gastropods in seagrass bed in Otsuchi Bay, north-eastern Japan. Marine Ecology, 20, 273-289. doi:10.1046/j.1439-0485.1999.2034082.x

[14] Rotherham, D. and West, R.J. (2002) Do different seagrass species support distinct fish communities in southeastern Australia? Fisheries Management and Ecology, 9, 235-248.

[15] Hyndes, G.A., Kendrick, A.J., MacArthur, L.D. and Steward, E. (2003) Differences in the species- and size- 
composition of fish assemblages in three distinct seagrass habitats with differing plant and meadow structure. $\mathrm{Ma}$ rine Biology, 142, 1195-1206.

[16] Hori, M., Suzuki, T., Monthum, Y., Srisombat, T., Tanaka, Y., Nakaoka, M. and Mukai, H. (2009) High seagrass diversity and canopy-height increase associated fish diversity and abundance. Marine Biology, 156, 1447-1458. doi:10.1007/s00227-009-1184-3

[17] Stoner, A.W. and Lewis, F.G. (1985). The influence of quantitative and qualitative aspects of habitat complexity in tropical seagrass meadows. Journal of Experimental Marine Biology and Ecology, 94, 19-40. doi:10.1016/0022-0981(85)90048-6

[18] Short, F.T., Polidoro, B., Livingstone, S.R., Carpenter, K.E., Bandeira, S., Bujang, J.S., Calumpong, H.P., Carruthers, T.J.B., Coles, R.G., Dennison, W.C., Erftemeijer, P.L.A., Fortes, M.D., Freeman, A.S., Jagtap, T.G., Kamal, A.H.M., Kendrick, G.A., Kenworthy, W.J., La Nafie, Y.A., Nasution, I.M., Orth, R.J., Prathep, A., Sanciangcho, J.C., van Tussenbroek, B., Vergara, S.G., Waycott, M. and Zieman, J.C. (2011) Extinction risk assessment of the world's seagrass species. Biological Conservation, 144, 1961-1971.

[19] Eggleston, D.B., Elis, W.E., Etherington, L.L., Dahlgren, C.P. and Posey, M.H. (1999) Organism responses to habitat fragmentation and diversity: Habitat colonization by estuarine macrofauna. Journal of Experimental Marine Biology and Ecology, 236, 107-132. doi:10.1016/S0022-0981(98)00192-0

[20] Bowden, D.A., Rowden, A.A. and Attrill, M.J. (2001) Effect of patch size and in-patch location on the infaunal macroinvertebrate assemblages of Zostera marina seagrass beds. Journal of Experimental Marine Biology and Ecology, 259, 133-154. doi:10.1016/S0022-0981(01)00236-2

[21] Ambo-Rappe, R. (2011) Seagrasses: An ecosystem under threat. Habitat fragmentation and heavy metal accumulation. Lambert Academic Publishing, Saarbrücken.

[22] Debinski, D.M. and Holt, R.D. (2000) A survey and overview of habitat fragmentation experiments. Conservation Biology, 14, 342-355. doi:10.1046/j.1523-1739.2000.98081.x

[23] Helzer, C.J. and Jelinski, D.E. (1999) The relative importance of patch area and perimeter-area ratio to grassland breeding birds. Ecological Applications, 9, 1448.

[24] McNeill, S.E. and Fairweather, P.G. (1993) Single large or several small marine reserves? An experimental approach with seagrass fauna. Journal of Biogeography, 20, 429440. doi: $10.2307 / 2845591$

[25] Eggleston, D.B., Etherington, L.L. and Elis, W.E. (1998) Organism response to habitat patchiness: Species and habitat-dependent recruitment of decapod crustaceans. Journal of Experimental Marine Biology and Ecology, 223, 111-132. doi:10.1016/S0022-0981(97)00154-8

[26] Irlandi, E.A., Ambrose, W.G. and Orlando, B.A. (1995) Landscape ecology and the marine environment: How spatial configuration of seagrass habitat influences growth and survival of the bay scallop. Oikos, 72, 307-313. doi: $10.2307 / 3546115$
[27] Mills, V.S. and Berkenbusch, K. (2009) Seagrass (Zostera muelleri) patch size and spatial location influence infaunal macroinvertebrate assemblages. Estuarine, Coastal and Shelf Science, 81, 123-129. doi:10.1016/j.ecss.2008.10.005

[28] Bell, S.S., Brooks, R.A., Robbins, B.D. and Fonseca, M.S. (2001) Faunal response to fragmentation in seagrass habitats: Implications for seagrass conservation. Biological Conservation, 100, 115-123. doi:10.1016/S0006-3207(00)00212-3

[29] Gillanders, B.M. (2006) Seagrasses, fish, and fisheries. In: Larkum, A.W.D., Orth, R.J. and Duarte, C.M., Eds., Seagrasses: Biology, Ecology and Conservation, Springer, Berlin, 503-536.

[30] Troost, D.G., Sutomo, A.B. and Wenno, L.F. (1976) Distribution and abundance of major zooplankton groups in Ambon Bay (Maluku, Indonesia) during a salp swarming, with notes on Chaetocnatha and Pteropoda species. Marine Reasearch in Indonesia, 16, 31-44.

[31] Waycott, M., McMahon, K., Mellors, J., Calladine, A. and Kleine, D. (2004) A guide to tropical seagrass of Indo-West Pacific. James Cook University, Townsville.

[32] McKenzie, L.J., Campbell, S.J. and Roder, C.A. (2003) Seagrass-Watch: Manual for mapping and monitoring seagrass resources by community (citizen) volunteers. 2nd Edition, QFS, NFC, Cairns.

[33] Allen, G. (1999) Marine fishes of South-East Asia: A field guide for anglers and divers. Periplus Editions, Singapore.

[34] Carpenter, K.E. and Niem, V.H. (2001) The living marine resources of the Western Central Pacific. Volume 6: bony fishes Part 4 (Labridae to Latimeriidae), estuarine crocodiles, sea turtles, sea snakes and marine mammals. Food and Agriculture of the United Nations, Rome.

[35] Kuiter, R.H. and Tonozuka, T. (2001) Pictorial guide to Indonesian reef fishes. PT Dive \& Dave's, Victoria.

[36] Coles, R.G., Lee Long, W.J. and Watson, R.A. (1993) Distribution of seagrasses, and their fish and Penaeid prawn communities, in Cairn Harbour, a tropical estuary, Northern Queensland, Australia. Australian Journal of Marine and Freshwater Research, 44, 193-210.

[37] Hair, C.A., Bell, J.D. and Kingsford, M.D. (1994) Effects of position in the water column, vertical movement and shade on settlement of fish to artificial habitats. Bulletin of Marine Science, 55, 434-444.

[38] Chittaro, P.M., Usseglio, P. and Sale, P.F. (2005) Variation in fish density, assemblage composition and relative rates of predation among mangrove, seagrass, and coral reef habitats. Environmental Biology of Fishes, 72, 175-187. doi:10.1007/s10641-004-9077-2

[39] Kimirei, I.A., Nagelkerken, I., Griffioen, B., Wagner, C. and Mgaya, Y.D. (2011) Ontogenetic habitat use by mangrove/seagrass-associated coral reef fishes shows flexibility in time and space. Estuarine, Coastal and Shelf Science, 92, 47-58. doi:10.1016/j.ecss.2010.12.016

[40] Bell, J.D. and Pollard, D.A. (1989) Ecology of fish assemblages and fisheries associated with seagrasses. In: Larkum, A.W.D., McComb, A.J. and Shepherd, S.A., Eds., 
Biology of Seagrasses: A Treatise on the Biology of Seagrasses with Special Reference to the Australasian Region, Elsevier, Amsterdam, 565-609.

[41] Beck, M.W., Heck, K.L., Able, K.W., Childers, D.L., Eggleston, D.B, Gillanders, B.M., Halpern, B., Hays, C.G., Hoshino, K., Minello, T.J., Orth, R.J., Sheridan, P.F. and Weinstein, M.P. (2001) The identification, conservation, and mangement of estuarine and marine nurseries for fish and invertebrates. Bioscience, 51, 633-641. doi:10.1641/0006-3568(2001)051[0633:TICAMO]2.0.C $\underline{\mathrm{O} ; 2}$

[42] Moura, R.L., Francini-Filho, R.B., Chaves, E.M., MinteVera, C.V. and Lindeman, K.C. (2011) Use of riverine through reef habitat systems by dog snapper (Lutjanus jocu) in eastern Brazil. Estuarine, Coastal and Shelf Science, 95, 274-278. doi:10.1016/j.ecss.2011.08.010

[43] De la Morinière, E.C., Pollux, B.J.A., Nagelkerken, I. and van der Velde, G. (2002) Post-settlement life cycle migration patterns and habitat preference of coral reef fish that use seagrass and mangrove habitats as nurseries. Estuarine, Coastal and Shelf Science, 55, 309-321. doi:10.1006/ecss.2001.0907

[44] Dorenbosch, M., van Riel, M.C., Nagelkerken, I. and van der Velde, G. (2004) The relationship of reef fish densities to the proximity of mangrove and seagrass nurseries. Estuarine, Coastal and Shelf Science, 60, 37-48. doi:10.1016/j.ecss.2003.11.018

[45] Horinouchi, M. (2007) Review of the effect of withinpatch scale structural complexity on seagrass species. Journal of Experimental Marine Biology and Ecology, 350, 111-129. doi:10.1016/j.jembe.2007.06.015

[46] Horinouchi, M. and Sano, M. (1999) Effect of changes in seagrass shoot density and leaf height on the abundances and distribution patterns of juveniles of three gobiid fishes in a Zostera marina bed. Marine Ecology Progress Series, 183, 87-94. doi:10.3354/meps183087

[47] Middleton, M.J., Bell, J.D., Burchmore, J.J., Pollard, D.A. and Pease, B.C. (1994) Structural differences in the fish communities of Zostera capricorni and Posidonia australis seagrass meadows in Botany Bay, New South Wales. Aquatic Botany, 18, 89-109. doi:10.1016/0304-3770(84)90082-2

[48] Kendrick, A.J. and Hyndes, G.A. (2003) Pattern in the abundance and size-distribution of syngnathid fishes among habitats in seagrass-dominated marine environment. Estuarine, Coastal and Shelf Science, 57, 631-640. doi:10.1016/S0272-7714(02)00402-X

[49] Rooker, J.R., Holt, S.A., Soto, M.A. and Holt, G.J. (1998) Post settlement patterns of habitat use by sciaenid fishes in subtropical seagrass meadows. Estuaries, 21, 318-327. doi: $10.2307 / 1352478$

[50] Stoner, A. (1982) The influence of benthic macrophytes on the foraging behavior of pinfish (Lagodon rhomboides) (Linneaeus). Journal of Experimental Marine Biology and Ecology, 58, 271-284. doi:10.1016/0022-0981(82)90134-4

[51] Bell, J.D. and Westoby, M. (1986) Variation in seagrass height and density over a wide spatial scale: Effects on common fish and decapods. Journal of Experimental Marine Biology and Ecology, 104, 275-295. doi:10.1016/0022-0981(86)90110-3

[52] Hannan, J.C. and Williams, R.J. (1998) Recruitment of juvenile marine fishes to seagrass habitat in a temperate Australian estuary. Estuaries, 21, 29-51. doi: $10.2307 / 1352545$ 